(c) 2018 - ISSN 1807-2577

\title{
Antimicrobial activity of mouth rinses against bacteria that initially colonizes dental's surface
}

\author{
Atividade antimicrobiana de enxaguatórios bucais sobre bactérias que iniciam \\ a colonização das superfícies dentais
}

\author{
Isaac Jordão de Souza ARAÚJOa ${ }^{(1)}$, Marília Souza de CARVALHO ${ }^{(1)}$, Thaís Rossini de OLIVEIRAa (i), \\ Regina Maria PUPPIN-RONTANIa (i), José Francisco HÖFLINGa (D), \\ Renata de Oliveira MATTOS-GRANER ${ }^{\mathrm{a}} \mathbb{1}$, Rafael Nóbrega STIPPa* \\ aUNICAMP - Universidade Estadual de Campinas, Faculdade de Odontologia de Piracicaba, Piracicaba, SP, Brasil
}

How to cite: Araújo IJS, Carvalho MS, Oliveira TR, Puppin-Rontani RM, Höfling JF, Mattos-Graner RO, et al. Antimicrobial activity of mouth rinses against bacteria that initially colonizes dental's surface. Rev Odontol UNESP. 2019;48:e20180130. https://doi.org/10.1590/1807-2577.13018

\begin{abstract}
Resumo
Introdução: Muita publicidade sobre enxaguatórios bucais é veiculada em todos os meios de comunicação apelando para o efeito anti-placa e prestando um desserviço à comunidade. Grande quantidade de enxaguatórios bucais está disponível no mercado e estes diferem em suas composições e eficácia antimicrobiana. Objetivo: Neste estudo, avaliamos a atividade antimicrobiana de 35 enxaguatórios bucais amplamente disponíveis contra espécies bacterianas envolvidas na iniciação do biofilme dental Streptococcus gordonii, Streptococcus mitis, Streptococcus oralis, Streptococcus salivarius e Streptococcus sanguinis. Material e método: A Concentração Inibitória Mínima (CIM) e a Concentração Bactericida Mínima (CBM) dos enxaguatórios avaliados foram determinadas de acordo com os protocolos do Clinical \& Laboratory Standards Institute. Os dados foram submetidos ao teste Kruskal-Wallis e Mann-Whitney post hoc $(\alpha=0,05)$. Resultado: Aproximadamente $70 \%$ dos enxaguatórios bucais alcançaram alta atividade antibacteriana e $30 \%$, baixa atividade antibacteriana contra todas as espécies testadas. 0 enxaguatório bucal mais ineficaz mostrou atividade antibacteriana (CIM) na diluição de 1:1, enquanto a mais eficaz mostrou atividade mesmo na diluição de 1:2048, o que pode implicar em efeito prolongado na boca. Cerca de $51 \%$ dos enxaguatórios bucais apresentaram atividade bactericida, e verificou-se que formulações contendo cloreto de cetilpiridíneo ou digluconato de clorexidina estavam associados à maior atividade. Conclusão: A maior parte - mas não todos - dos enxaguatórios bucais comercialmente disponíveis são eficazes na inibição de colonizadores iniciais de superfícies dentárias in vitro.
\end{abstract}

Descritores: Microbiologia; agentes antimicrobianos; enxaguatórios bucais; biofilmes.

\begin{abstract}
Introduction: Much advertising in mouthwash is conveyed in all media appealing to the anti-plaque effect and rendering a disservice to the community. Mouth rinses are available over-the-count and differ on their compositions and antimicrobial effectiveness. Objective: In this study, we evaluated the antimicrobial activity of 35 widely available mouth rinses against bacterial species involved in initiation of dental biofilm - Streptococcus gordonii, Streptococcus mitis, Streptococcus oralis, Streptococcus salivarius, and Streptococcus sanguinis. Material and method: The Minimum Inhibitory Concentration (MIC) and the Minimum Bactericidal Concentration (MBC) of the evaluated mouth rinses were determined according to the Clinical \& Laboratory Standards Institute protocols. Data were submitted to Kruskal-Wallis test and Mann-Whitney post hoc $(\alpha=0.05)$. Result: About $70 \%$ of the mouth rinses achieved high antibacterial activity and $30 \%$, a low antibacterial activity against all the species tested. The most ineffective mouth rinse showed antibacterial activity (MIC) at 1:1 dilution, while the most effective showed activity even at 1:2048 dilution, which may imply prolonged effect in the mouth. About $51 \%$ of mouth rinses showed bactericidal activity, and it was verified that cetylpyridinium chloride or chlorhexidine digluconate containing in the
\end{abstract}


formulation were associated with the highest activity. Conclusion: Most - but not all - mouth rinses commercially available are effective in inhibiting in vitro initial colonizers of dental surfaces.

Descriptors: Microbiology; antimicrobial agents; mouth rinses; biofilms.

\section{INTRODUCTION}

Oral cavity represents one of the body surfaces with greater abundance and diversity of microorganisms. Dental biofilms consist of at least 800 bacterial species $^{1}$. Within its first $6 \mathrm{~h}$ of formation, dental biofilm microbiota is mainly comprised by Streptococci species, including Streptococcus mitis, Streptococcus oralis, Streptococcus salivarius, Streptococcus gordonii and Streptococcus sanguinis ${ }^{2,3}$, due to adhesins that have an affinity to host dental-pellicle and other factors ${ }^{1}$.

Although considered non-pathogenic, these Streptococci dental biofilm pioneer species modifies the ecological environment and allow biofilm accumulation and maturation, a condition that may lead to diseases, such as dental caries and periodontal diseases ${ }^{1,2}$. A frequent removal of the biofilm by mechanical ways - brushing and flossing - are the main methods for dental biofilm control ${ }^{4}$. Coadjutant to the mechanical control, chemical solutions, including mouth rinses, may contribute to postpone the biofilm re-formation and thus, its maturation ${ }^{4}$. Besides, a recent in vivo study evidenced a reduced plaque accumulation and gingivitis after six months of chemicalmechanical compared to mechanical control alone ${ }^{5}$.

In this sense, many chemical agents, with different active principles, are used in biofilm control. Cetylpyridinium chloride (CPC), essential oils, sodium fluoride, chlorhexidine (CHX) and, triclosan are commonly used and the effectiveness of these compounds is apparently associated with action spectrum, substantivity in the oral cavity and their action at permissible concentrations ${ }^{6}$. Specific mechanisms of action characterize and distinguish the mouth rinses: CPC is an ammonium quaternary that affects microbial proteins and lipids ${ }^{7}$, while essential oils are phenolic compounds that can penetrate cell membrane ${ }^{8}$. Apart from that, chlorhexidine is a cationic compound that binds to bacteria membrane phospholipids ${ }^{9}$ and triclosan blocks fattyacids biosynthesis inhibiting enoyl reductase enzyme ${ }^{10}$.

Furthermore, different concentrations lead to particularities in mouth rinses effectiveness. Also, the combination of active principles and other substances may contribute to the synergic effect or to improve substantivity ${ }^{6,11}$. These variations difficult the establishment/determination of the mouth rinses clinical effectiveness.

In addition, many studies have evaluated the effects of chemical agents on S. mutans ${ }^{12,13}$, an important agent in caries development, but not responsible for the first stages in initial colonization of the substrate. Thus, there is no direct association with the microorganisms involved in initial biofilms development.

Once early colonizers can modify the oral microenvironment and facilitate biofilm structuration ${ }^{2}$, it is important to establish the best properties of a mouth rinse on biofilm control. Moreover, it is essential to understand the role of different mouth rinses formulations on initial biofilm inhibition.

Therefore, we evaluated the antimicrobial activity of 35 commercial mouth rinses, against bacterial species mainly responsible for initiating dental biofilm. The null hypothesis of this study is that there is no significant difference between different compounds on antibacterial activity of different mouth rinses. 


\section{MATERIAL AND METHOD}

\section{Strains}

Five species associated with biofilm initiation on tooth surfaces were evaluated: Streptococcus sanguinis (ATCC ${ }^{\circledR}$ BAA-1455), Streptococcus mitis (ATCC ${ }^{\circledR}$ 49456), Streptococcus oralis (ATCC ${ }^{\circledR}$ 10557), Streptococcus salivarius (ATCC ${ }^{\circledR}$ 7073), and Streptococcus gordonii (ATCC ${ }^{\circledR}$ 35105). Strains were purchased from ATCC ${ }^{\circledR}$ and stored in Skim Milk (BD Difco, NJ, USA) at $-70{ }^{\circ} \mathrm{C}$. Pure cultures were analyzed by Gram staining and cultivation on Brain Heart Infusion (BHI) agar (BD Difco).

\section{Mouth Rinses Selection}

Thirty-five mouth rinses available on the market were evaluated (Table 1). Inclusion criteria were as follows: be available in at least three large-sized supermarkets localized in four cities from São Paulo state (Campinas, Piracicaba, Santos and São Paulo) and be available at Internet for whole country orders. The study was blinded concerning the mouth rinse brand. Each mouth rinse was fractionated in standard plastic tubes, coded, and assayed by researches that did not know products brands. Expiration date was greater than 6 months on the days which mouth rinses were assayed. CRIS Guidelines ${ }^{14}$ were followed to promote quality and transparency in this report.

\section{Mouth Rinses Minimum Inhibitory Concentration and Minimum Bactericidal Concentrations}

Minimum Inhibitory Concentrations (MIC) and Minimum Bactericidal Concentrations (MBC) assays were carried out according to the micro-dilution method recommended by The Clinical and Laboratory Standards Institute (CLSI M07-A10) ${ }^{15}$. For the inoculum, strains were grown in Mitis Salivarius Agar (MSA, BD Difco) at $37{ }^{\circ} \mathrm{C}, 10 \% \mathrm{CO}_{2}$, for $24 \mathrm{~h}$. Bacterial colonies were transferred to $5 \mathrm{~mL}$ of $\mathrm{BHI}$ and incubated $\left(37^{\circ} \mathrm{C}, 10 \% \mathrm{CO}_{2}, 18 \mathrm{~h}\right)$. Absorbance $(550 \mathrm{~nm})$ of grew cultures were adjusted to 0.05 with fresh BHI. Mouth rinses were diluted by 2 -fold from pure to 1:2048 with BHI in the wells of 96-well plates. One hundred microliters of adjusted inoculum were mixed with $100 \mu \mathrm{L}$ of diluted mouth rinses. Therefore, mouth rinses were evaluated at final concentrations ranging from $1: 1$ to $1: 4096$. Plates were incubated at $37{ }^{\circ} \mathrm{C}, 10 \% \mathrm{CO}_{2}$ and the visible bacterial growth was evaluated after $24 \mathrm{~h}$. MIC was defined as the lowest concentration that prevented visible growth. To determine MBCs, wells with no visible growth were homogenized and aliquots of $20 \mu \mathrm{L}$ were transferred in triplicate to BHI agar plates followed by incubation $\left(37^{\circ} \mathrm{C}, 10 \% \mathrm{CO}_{2}, 48 \mathrm{~h}\right)$.

Positive control for bacterial viability was prepared in wells without mouth rinse. Negative controls included sterile media with mouth rinses or without. Chlorhexidine digluconate (Sigma Aldrich, MO, USA) at $0.12 \%$ and its dilutions (1:1 to $1: 4096)$ were used to assess the reproducibility assay and as positive control of the bacterial death. Assays were performed in duplicate in three independent replicates.

Then, data were plotted and described in mean scores according to the number of dilutions as presented in Table 1. The scores represent the integer number corresponding to the well of MIC means. Non-integer averages were not rounded up and a conservative mean was adopted to record data in Table 2 . The greater the score, the greater bacteria inhibition exhibited by mouth rinse. 
Table 1. Number of dilutions, mean scores and mouth rinses concentration (\%) used to describe antimicrobial activity

\begin{tabular}{ccc}
\hline Dilution & Score & Mouth rinses concentration \\
\hline $1: 1$ & 1 & $50 \%$ \\
$1: 2$ & 2 & $25 \%$ \\
$1: 4$ & 3 & $12.5 \%$ \\
$1: 8$ & 4 & $6.25 \%$ \\
$1: 16$ & 5 & $3.125 \%$ \\
$1: 32$ & 6 & $1.5625 \%$ \\
$1: 64$ & 7 & $0.78125 \%$ \\
$1: 128$ & 8 & $0.390625 \%$ \\
$1: 256$ & 9 & $0.1953125 \%$ \\
$1: 512$ & 10 & $0.09765625 \%$ \\
$1: 1024$ & 11 & $0.04882812 \%$ \\
$1: 2048$ & 12 & $0.02441406 \%$ \\
$1: 4096$ & 13 & $0.01220703 \%$ \\
\hline
\end{tabular}

\section{Statistical Analysis}

Data normality was verified using the Kolmogorov-Smirnov test. Data with non-normal distribution were submitted to Kruskal-Wallis test followed by Mann-Whitney post hoc with peer comparison. Significant level was set at 5\%. Statistical analysis was done using the SPSS Statistics software (version 21; IBM Corp., NY, USA).

\section{RESULT}

Mouth rinses and their main active ingredients, bacterial inhibition scores, and antibacterial activity are shown in Table 2 . Of the mouth rinses evaluated, $86 \%$ have sodium fluoride at 225 or $226 \mathrm{ppm}$ in their composition. Cetylpyridinium chloride was the most frequent antimicrobial agent used by the manufacturers, being in composition of $45 \%$ of the mouth rinses tested (Table 2). Essential oils are widely used among mouth rinses and were listed either as active or inactive ingredient by the manufacturers.

The mouth rinses showed similar behavior in their inhibitory activity among the species (Table 2), since the MIC assays resolutions is \pm 1 . Therefore, the greater integer of mean (conservative mean) was considered for mouth rinses finals' scoring.

MIC assays results were analyzed accordingly to CLSI (M07-A10) ${ }^{15}$ and recommended statistical analysis where applied to define break points ${ }^{15}$. Thus, mouth rinses could be divided in two major groups: those with inhibition value equal-below score 5 , which we classified as a low antibacterial activity, or equal-above score 8 , ones with a higher antibacterial activity.

About $70 \%$ of the mouth rinses achieved a high antibacterial activity (score $\geq 8$ ) and $30 \%$, a low antibacterial activity (score $\leq 5$ ) (Table 2). It was evidenced that $51.4 \%$ of mouth rinses have a bactericidal activity and this was associated with the presence of cetylpyridinium chloride, essential oils associated with fluorine, or chlorhexidine digluconate compounds. 
Table 2. List of mouth rinses evaluated, main active(s) ingredient(s), conservative mean* for each species, and antimicrobial activity

\begin{tabular}{|c|c|c|c|c|c|c|c|c|}
\hline $\begin{array}{l}\text { Mouth rinse } \\
\text { (brand) }\end{array}$ & $\begin{array}{l}\text { Main active(s) } \\
\text { ingredient(s) }\end{array}$ & $\begin{array}{c}S . \\
\text { mitis }\end{array}$ & $\begin{array}{c}\text { S. } \\
\text { sanguinis }\end{array}$ & S. oralis & S. salivarius & $\begin{array}{c}S . \\
\text { gordonii }\end{array}$ & $\begin{array}{c}\text { Conservative } \\
\text { mean* }\end{array}$ & Activity \\
\hline Positive control & $0.12 \%$ & & & & & & & \\
\hline $\begin{array}{c}\text { - Chlorhexidine } \\
0.12 \%\end{array}$ & $\begin{array}{l}\text { Chlorhexidine } \\
\text { digluconate }\end{array}$ & 12 & 11 & 10 & 12 & 11 & $11^{\mathrm{a}}$ & Bactericidal \\
\hline Cepacol Flúor & $\begin{array}{l}\text { Cetylpyridinium } \\
\text { chloride, } 226 \mathrm{ppm} \\
\text { sodium fluoride }\end{array}$ & 12 & 11 & 12 & 12 & 11 & $11^{\mathrm{a}}$ & Bactericidal \\
\hline Cepacol Menta & $\begin{array}{l}\text { Cetylpyridinium } \\
\text { chloride }\end{array}$ & 11 & 10 & 11 & 10 & 10 & $10^{\mathrm{a}}$ & Bactericidal \\
\hline Cepacol Original & $\begin{array}{l}\text { Cetylpyridinium } \\
\text { chloride }\end{array}$ & 12 & 11 & 11 & 12 & 11 & $11^{\mathrm{a}}$ & Bactericidal \\
\hline $\begin{array}{l}\text { Colgate Plax } \\
\text { Classic Splash }\end{array}$ & $\begin{array}{l}\text { Cetylpyridinium } \\
\text { chloride, } 226 \mathrm{ppm} \\
\text { sodium fluoride }\end{array}$ & 11 & 10 & 11 & 11 & 10 & $10^{\mathrm{a}}$ & Bactericidal \\
\hline $\begin{array}{c}\text { Colgate Plax Fresh } \\
\text { Mint }\end{array}$ & $\begin{array}{l}\text { Cetylpyridinium } \\
\text { chloride, } 226 \text { ppm } \\
\text { sodium fluoride }\end{array}$ & 13 & 12 & 12 & 13 & 12 & $12^{\mathrm{a}}$ & Bactericidal \\
\hline $\begin{array}{l}\text { Colgate Plax Ice } \\
\text { Infinity }\end{array}$ & $\begin{array}{l}\text { Cetylpyridinium } \\
\text { chloride, } 226 \mathrm{ppm} \\
\text { sodium fluoride }\end{array}$ & 13 & 10 & 12 & 12 & 11 & $11^{\mathrm{a}}$ & Bactericidal \\
\hline $\begin{array}{c}\text { Colgate Plax Soft } \\
\text { Mint }\end{array}$ & $\begin{array}{l}\text { Cetylpyridinium } \\
\text { chloride, } 226 \mathrm{ppm} \\
\text { sodium fluoride }\end{array}$ & 12 & 12 & 12 & 13 & 12 & $12^{\mathrm{a}}$ & Bactericidal \\
\hline $\begin{array}{l}\text { Colgate Tea } \\
\text { Fresh }\end{array}$ & $\begin{array}{l}\text { Plants extracts, } \\
\text { cetylpyridinium } \\
\text { chloride, } 226 \mathrm{ppm} \\
\text { sodium fluoride }\end{array}$ & 12 & 11 & 11 & 12 & 10 & $11^{\mathrm{a}}$ & Bactericidal \\
\hline $\begin{array}{c}\text { Dental Fresh } \\
\text { Whitening Menta }\end{array}$ & $\begin{array}{l}\text { Cetylpyridinium } \\
\text { chloride, } 226 \text { ppm } \\
\text { sodium fluoride }\end{array}$ & 11 & 11 & 11 & 12 & 11 & $11^{\mathrm{a}}$ & Bacteriostatic \\
\hline $\begin{array}{l}\text { Dr Axell Ação } \\
\text { Total sem álcool }\end{array}$ & $\begin{array}{l}\text { Cetylpyridinium } \\
\text { chloride, } 225 \mathrm{ppm} \\
\text { sodium fluoride }\end{array}$ & 10 & 10 & 10 & 10 & 9 & $9^{a}$ & Bacteriostatic \\
\hline $\begin{array}{l}\text { Dr Axell Cool } \\
\text { Mint Extra Forte } \\
\text { com álcool }\end{array}$ & $\begin{array}{l}\text { Cetylpyridinium } \\
\text { chloride }\end{array}$ & 11 & 11 & 11 & 12 & 11 & $11^{\mathrm{a}}$ & Bacteriostatic \\
\hline $\begin{array}{l}\text { Natural Honey } \\
\text { Menta Fresh }\end{array}$ & $\begin{array}{c}\text { Cetylpyridinium } \\
\text { chloride, propolis } \\
\text { extract, } 226 \mathrm{ppm} \\
\text { sodium fluoride }\end{array}$ & 11 & 11 & 10 & 11 & 10 & $10^{\mathrm{a}}$ & Bactericidal \\
\hline $\begin{array}{l}\text { Oral B Complete } \\
\text { Spearmint }\end{array}$ & $\begin{array}{l}\text { Cetylpyridinium } \\
\text { chloride, } 226 \mathrm{ppm} \\
\text { sodium fluoride }\end{array}$ & 12 & 11 & 11 & 12 & 11 & $11^{\mathrm{a}}$ & Bactericidal \\
\hline $\begin{array}{c}\text { Oral B Complete } \\
\text { Mint }\end{array}$ & $\begin{array}{l}\text { Cetylpyridinium } \\
\text { chloride, } 226 \mathrm{ppm} \\
\text { sodium fluoride }\end{array}$ & 12 & 11 & 11 & 12 & 12 & $11^{\mathrm{a}}$ & Bactericidal \\
\hline $\begin{array}{l}\text { Oral B Pró-saude } \\
\text { Clinical } \\
\text { Protection }\end{array}$ & $\begin{array}{l}\text { Cetylpyridinium } \\
\text { chloride }\end{array}$ & 12 & 11 & 11 & 12 & 11 & $11^{\mathrm{a}}$ & Bactericidal \\
\hline Periogard & $\begin{array}{c}0.12 \% \\
\text { Chlorhexidine } \\
\text { digluconate }\end{array}$ & 12 & 11 & 10 & 12 & 11 & $11^{\mathrm{a}}$ & Bactericidal \\
\hline Sensodyne & $\begin{array}{l}\text { Cetylpyridinium } \\
\text { chloride, } 226 \mathrm{ppm} \\
\text { sodium fluoride }\end{array}$ & 12 & 9 & 10 & 11 & 9 & $10^{\mathrm{a}}$ & Bacteriostatic \\
\hline
\end{tabular}


Table 2. Continued..

\begin{tabular}{|c|c|c|c|c|c|c|c|c|}
\hline $\begin{array}{l}\text { Mouth rinse } \\
\text { (brand) }\end{array}$ & $\begin{array}{l}\text { Main active(s) } \\
\text { ingredient(s) }\end{array}$ & $\begin{array}{c}S . \\
\text { mitis }\end{array}$ & $\begin{array}{c}\text { S. } \\
\text { sanguinis }\end{array}$ & S. oralis & S. salivarius & $\begin{array}{c}S . \\
\text { gordonii }\end{array}$ & $\begin{array}{c}\text { Conservative } \\
\text { mean* }\end{array}$ & Activity \\
\hline Listerine & Essential oils, & & & & & & & \\
\hline $\begin{array}{c}\text { Essential Fresh } \\
\text { Mint }\end{array}$ & $\begin{array}{l}221 \text { ppm sodium } \\
\text { fluoride }\end{array}$ & 9 & 8 & 9 & 9 & 8 & $8 \mathrm{ab}$ & Bactericidal \\
\hline Listerine & Essential oils, & & & & & & & \\
\hline $\begin{array}{c}\text { Essential Ice } \\
\text { Mint }\end{array}$ & $\begin{array}{l}221 \mathrm{ppm} \text { sodium } \\
\text { fluoride }\end{array}$ & 9 & 8 & 9 & 9 & 8 & 8 ab & Bactericidal \\
\hline $\begin{array}{c}\text { Listerine } \\
\text { Essential Lemon }\end{array}$ & $\begin{array}{l}\text { Essential oils, } \\
221 \text { ppm sodium } \\
\text { fluoride }\end{array}$ & 8 & 8 & 9 & 9 & 8 & 8 ab & Bactericidal \\
\hline $\begin{array}{c}\text { Listerine } \\
\text { Whitening Mint }\end{array}$ & $\begin{array}{c}\text { Essential oils, } \\
\text { hydrogen peroxide }\end{array}$ & 8 & 8 & 8 & 9 & 8 & 8 ab & Bactericidal \\
\hline $\begin{array}{l}\text { Listerine Zero } \\
\text { Menta Suave }\end{array}$ & $\begin{array}{c}\text { Essential oils, } \\
\text { sodium lauryl } \\
\text { sulfate }\end{array}$ & 9 & 8 & 9 & 9 & 7 & 8 ab & Bacteriostatic \\
\hline $\begin{array}{l}\text { Listerine Zero } \\
\text { Menta Verde }\end{array}$ & $\begin{array}{l}\text { Essential oils, } \\
\text { sodium lauryl } \\
\text { sulfate }\end{array}$ & 9 & 8 & 8 & 9 & 8 & 8 ab & Bacteriostatic \\
\hline Anapyon & $\begin{array}{l}\text { Plants extracts, } \\
\text { cetylpyridinium } \\
\text { chloride }\end{array}$ & 5 & 4 & 5 & 4 & 4 & $4^{b}$ & Bacteriostatic \\
\hline $\begin{array}{l}\text { Closeup D. } \\
\text { Attraction } \\
\text { Delicate Fresh }\end{array}$ & $\begin{array}{l}226 \text { ppm sodium } \\
\text { fluoride }\end{array}$ & 2 & 1 & 1 & 1 & 1 & $1^{b}$ & Bacteriostatic \\
\hline $\begin{array}{l}\text { Closeup D. } \\
\text { Attraction Power } \\
\text { White }\end{array}$ & $\begin{array}{l}226 \text { ppm sodium } \\
\text { fluoride }\end{array}$ & 2 & 2 & 2 & 1 & 2 & $1^{b}$ & Bacteriostatic \\
\hline $\begin{array}{c}\text { Closeup } \\
\text { Platinum Fresh }\end{array}$ & Essential oils & 4 & 5 & 4 & 4 & 4 & $4^{b}$ & Bacteriostatic \\
\hline $\begin{array}{l}\text { Listerine Cool } \\
\text { Citrus }\end{array}$ & Essential oils & 2 & 3 & 2 & 2 & 2 & $2 \mathrm{~b}$ & Bacteriostatic \\
\hline $\begin{array}{l}\text { Listerine Cool } \\
\text { Mint Hortelã }\end{array}$ & Essential oils & 2 & 2 & 2 & 2 & 2 & $2^{b}$ & Bacteriostatic \\
\hline Listerine & Essential oils, & & & & & & & \\
\hline $\begin{array}{l}\text { Cuidado Total } \\
\text { Menta }\end{array}$ & $\begin{array}{l}221 \text { ppm sodium } \\
\text { fluoride }\end{array}$ & 4 & 4 & 4 & 4 & 4 & $4^{b}$ & Bacteriostatic \\
\hline $\begin{array}{l}\text { Listerine Defesa } \\
\text { Menta }\end{array}$ & $\begin{array}{l}\text { Essential oils, } \\
221 \text { ppm sodium } \\
\text { fluoride }\end{array}$ & 4 & 4 & 4 & 3 & 4 & $3 \mathrm{~b}$ & Bacteriostatic \\
\hline $\begin{array}{c}\text { Listerine } \\
\text { Freshbrust Mint }\end{array}$ & Essential oils & 2 & 3 & 2 & 3 & 2 & $2 \mathrm{~b}$ & Bacteriostatic \\
\hline $\begin{array}{l}\text { Listerine Tartar } \\
\text { Control Mint }\end{array}$ & $\begin{array}{l}\text { Essential oils, zinc } \\
\text { chloride }\end{array}$ & 5 & 6 & 5 & 5 & 5 & $5^{b}$ & Bacteriostatic \\
\hline $\begin{array}{l}\text { Malvatricin Plus } \\
5 \mathrm{em} 1\end{array}$ & $\begin{array}{l}\text { Triclosan, Malva } \\
\text { sylvestris extract, } \\
225 \text { ppm sodium } \\
\text { fluoride }\end{array}$ & 7 & 5 & 6 & 6 & 5 & $5^{b}$ & Bacteriostatic \\
\hline $\begin{array}{l}\text { Malvatrikids } \\
\text { Junior }\end{array}$ & $\begin{array}{l}\text { Malva sylvestris } \\
\text { extract, } 225 \mathrm{ppm} \\
\text { sodium fluoride }\end{array}$ & 7 & 6 & 5 & 5 & 5 & $5^{b}$ & Bacteriostatic \\
\hline
\end{tabular}

*Minimum integer of the mean. Different lower letters indicate statistical differences between mouth rinses MIC $(\mathrm{p}<0.05)$, Kruskal-Wallis with Dunn's post hoc. 
Mouth rinses composed by essential oils as sole antimicrobial agent showed lower antibacterial activity (mean score $5.7 \pm 2.3$ ) compared to cetylpyridinium chloride or chlorhexidine digluconate-based products (mean score $10.5 \pm 1.7$ ) ( $<0.01$, Kruskal-Wallis). As essential oils, sodium fluoride used alone in mouth rinses exhibited low antimicrobial activity for all analyzed species compared to cetylpyridinium chloride materials $(\mathrm{p}<0.01)$.

On the other hand, combinations between sodium fluoride and essential oils or other active principles were effective controlling the oral microorganisms evaluated in this study. In the same way, essential oils combined with tens active detergent (sodium lauryl sulfate) (8.4 \pm 0.7$)$ and disinfectant (hydrogen peroxide) $(8.0 \pm 0.4)$ were effective to control early colonizers.

\section{DISCUSSION}

Dental biofilm control is essential for preventing major infectious oral diseases 3 . Mechanical biofilm removal is effective in reducing attached bacteria and mouth rinses have been used as adjuvants for reduction of the bacterial load ${ }^{16}$.

Different active principles of mouth rinses influence on their antimicrobial activity ${ }^{16}$. Chlorhexidine digluconate appears to be the most effective antimicrobial agent ${ }^{16}$, but over-the-count mouth rinses widely available are mainly composed by the antimicrobial agent cetylpyridinium chloride (Table 2). The effectiveness of an antimicrobial agent in the oral cavity is also influenced by its substantivity ${ }^{11}$.

However, the different active principles and different available concentrations generate doubts about the influence of these variations on substantivity, specific action sites, toxicity and permeability of the chemical agent. These characteristics are relevant because they play an important role in the effectiveness in oral microorganisms' control ${ }^{6}$.

To contribute for these questions, in our results, mouth rinses were divided in two major groups: those with inhibition value below score $8(30 \%)$, which represents a low antibacterial activity, or equal-above score 8 (70\%), ones with a higher antibacterial activity. This difference was intrinsically related to the antimicrobial active ingredient and its' concentrations in each product tested. In this sense, supported by the differences among antimicrobial activities of the mouth rinses analyzed in this study, the null hypothesis was rejected.

Moreover, we found that products with declared same concentrations of an active ingredient somewhat may differ in their inhibitions scores (Table 2). These products were re-assayed and the inhibitions scores obtained were reproducible. These differences may be due bioavailability of the active principle when combined with other substances from the products' formula, as reported somewhere ${ }^{17}$.

Chlorhexidine digluconate is an antimicrobial agent used in few widely commercially available mouth rinses. Our results showed that products based in CHX have high bacterial inhibition (Table 2), agreeing with published studies (reviewed by Slot et al. ${ }^{16}$ ). CHX is a cationic molecule that binds nonspecifically to negatively-charged membrane phospholipids of microorganisms 9 . Solutions of chlorhexidine digluconate at $0.12 \%$ are clinically effective in reducing biofilm formation ${ }^{18}$ and our study shows CHX $0.12 \%$ can inhibit bacterial growth even at further 1:2048 dilution (Table 2).

Likewise, our results show the products containing CPC achieved the highest inhibition scores, as well as those having CHX. Most mouth rinses containing CPC inhibited bacterial growth of all tested strains even at low concentrations, such as 1:2048 (Table 2). As a cationic quaternary ammonium agent, CPC targets microbial proteins and lipids ${ }^{7}$ and can reduce insoluble glucan synthesis ${ }^{19}$. Furthermore, CPC may also affect the expression of bacterial genes involved with halitosis $^{20}$ and, at high concentrations, it causes cell membrane dissolution and consequent extravasation of the cytoplasmic content ${ }^{17}$. 
In contrast, pure essential oils-based mouth rinses showed lower antimicrobial activity comparing with those containing CPC or CHX -based products. This in contrast with the findings of other study 21 , a condition that may be related to the oil extraction methods or the level of purity of essential oils, conditions that affect their antimicrobial activity ${ }^{19}$. On the other hand, compounds like sodium lauryl sulfate and hydrogen peroxide were capable to improve antimicrobial effect of essential oils products. The possible explanations for those data are that sodium lauryl sulfate and hydrogen peroxide are surfactant and disinfectant, respectively, and may cause potential inhibitory effect on oral streptococci22,23. Besides, sodium fluoride (NaF) at $226 \mathrm{ppm}$ was also combined with essential oils and this combination exhibited a synergic effect.

Although $\mathrm{NaF}$ has presented effective results in combination with essential oils and $\mathrm{CPC}, \mathrm{NaF}$ alone has negligible antibacterial activity, since poor antimicrobial activity was evidenced in mouth rinses with solely $\mathrm{NaF}$ as active principle. However, $\mathrm{NaF}$ has efficacy in preventing dental caries by several biochemical mechanisms (reviewed by Ten Cate ${ }^{24}$ ) instead antibacterial activity.

Among the mouth rinses, triclosan was used as antimicrobial agent in only one product, which showed a low inhibitory activity. Triclosan is an antimicrobial agent that affects the fatty-acid biosynthesis in bacterial cells ${ }^{10}$. It was widely used in the mouth rinses in the past, but seems to be in disuse in consumer care products due possible healthy issues 25 .

Though clinical performance of mouth rinses depends of many variables, like concentration of active principle, substantivity, individual health condition, and host microbiota, there is a linear correlation between results of in vitro assays to in vivo mouth rinses' clinical performance ${ }^{17}$. In a critical view, it is difficult to isolate some significant factors in mouth rinses activity because manufacturers do not describe precisely the concentration of active principles and the balance between them and the other formula compounds. Nevertheless, our results can compare the effects of each commercially available solution over initial colonizers and predict the behavior of those compounds in mouth.

Furthermore, the efficacy of mouth rinses to inhibit early colonizers, evidenced in this study, reinforce the importance of including oral mouth rinses as adjuvant in oral hygiene associated to mechanical control of biofilm. As evidenced before, by this way, it would be possible to reduce plaque accumulation and gingival bleeding index ${ }^{5}$ which may be significant in individuals who perform buccal hygiene with low frequency or do not have enough motor ability to do properly brushing.

\section{CONCLUSION}

The antimicrobial activity of mouth rinses commercially available strongly vary, but in general, the majority of them, based on $\mathrm{CPC}+\mathrm{NaF}$ and $\mathrm{CHX}$, presented a high inhibition potential against species that are early dental biofilm colonizers and could be used as a helpful agent when associated with a mechanical oral hygiene.

\section{ACKNOWLEDGEMENTS}

Authors thank to Coordination for the Improvement of Higher Education Personnel (CAPES/PROAP) and Fund for Teaching, Research and Extension (FAEPEX/UNICAMP) for the financial support. The funders had no role in study design, data collection and analysis, decision to publish, or preparation of the manuscript. 


\section{REFERENCES}

1. Kolenbrander PE, Andersen RN, Blehert DS, Egland PG, Foster JS, Palmer RJ Jr. Communication among oral bacteria. Microbiol Mol Biol Rev. 2002 Sep;66(3):486-505. http://dx.doi.org/10.1128/MMBR.66.3.486-505.2002. PMid:12209001.

2. Li J, Helmerhorst EJ, Leone CW, Troxler RF, Yaskell T, Haffajee AD, et al. Identification of early microbial colonizers in human dental biofilm. J Appl Microbiol. 2004;97(6):1311-8. http://dx.doi.org/10.1111/j.1365-2672.2004.02420.x. PMid:15546422.

3. Heller D, Helmerhorst EJ, Gower AC, Siqueira WL, Paster BJ, Oppenheim FG. Microbial diversity in the early, in vivo -formed, dental biofilm. Appl Environ Microbiol. 2016 Mar;82(6):1881-8. http://dx.doi.org/10.1128/AEM.03984-15. PMid:26746720.

4. Sälzer S, Slot DE, Van Der Weijden FA, Dörfer CE. Efficacy of inter-dental mechanical plaque control in managing gingivitis: a meta-review. J Clin Periodontol. 2015 Apr;42(Suppl 16):S92-105. http://dx.doi.org/10.1111/jcpe.12363. PMid:25581718.

5. Lynch MC, Cortelli SC, McGuire JA, Zhang J, Ricci-Nittel D, Mordas CJ, et al. The effects of essential oil mouthrinses with or without alcohol on plaque and gingivitis: a randomized controlled clinical study. BMC Oral Health. 2018 Jan;18(1):6. http://dx.doi.org/10.1186/s12903-017-0454-6. PMid:29321067.

6. Sanz M, Serrano J, Iniesta M, Santa Cruz I, Herrera D. Antiplaque and antigingivitis toothpastes. Monogr Oral Sci. 2013;23:27-44. http://dx.doi.org/10.1159/000350465. PMid:23817058.

7. McDonnell G, Russell AD. Antiseptics and disinfectants: activity, action, and resistance. Clin Microbiol Rev. 1999 Jan;12(1):147-79. http://dx.doi.org/10.1128/CMR.12.1.147. PMid:9880479.

8. Ouhayoun JP. Penetrating the plaque biofilm: impact of essential oil mouthwash. J Clin Periodontol. 2003;30(Suppl 5):10-2. http://dx.doi.org/10.1034/j.1600-051X.30.s5.4.x. PMid:12787196.

9. Karpiński TM, Szkaradkiewicz AK. Chlorhexidine-pharmaco-biological activity and application. Eur Rev Med Pharmacol Sci. 2015 Apr;19(7):1321-6. PMid:25912596.

10. Levy CW, Roujeinikova A, Sedelnikova S, Baker PJ, Stuitje AR, Slabas AR, et al. The molecular basis of inhibition of enoyl reductase by triclosan. Nature. 1999 Apr;398:383-4. http://dx.doi.org/10.1038/18803. PMid:10201369.

11. Elworthy A, Greenman J, Doherty FM, Newcombe RG, Addy M. The substantivity of a number of oral hygiene products determined by the duration of effects on salivary bacteria. J Periodontol. 1996 Jun;67(6):572-6. http://dx.doi.org/10.1902/jop.1996.67.6.572. PMid:8794966.

12. Wakamatsu R, Takenaka S, Ohsumi T, Terao Y, Ohshima H, Okiji T. Penetration kinetics of four mouthrinses into Streptococcus mutans biofilms analyzed by direct time-lapse visualization. Clin Oral Investig. 2014;18(2):625-34. http://dx.doi.org/10.1007/s00784-013-1002-7. PMid:23716063.

13. Latimer J, Munday JL, Buzza KM, Forbes S, Sreenivasan PK, McBain AJ. Antibacterial and anti-biofilm activity of mouthrinses containing cetylpyridinium chloride and sodium fluoride. BMC Microbiol. 2015 Aug;15(1):169. http://dx.doi.org/10.1186/s12866-015-0501-x. PMid:26293609.

14. Krithikadatta J, Datta M, Gopikrishna V. CRIS Guidelines (Checklist for Reporting In-vitro Studies): a concept note on the need for standardized guidelines for improving quality and transparency in reporting in-vitro studies in experimental dental research. J Conserv Dent. 2014 Jul;17(4):301-4. http://dx.doi.org/10.4103/0972-0707.136338. PMid:25125839.

15. Clinical and Laboratory Standards Institute - CLSI. Methods for dilution antimicrobial susceptibility tests for bacteria that grow aerobically: approved standard. 10th ed. Wayne: CLSI; 2015. CLSI document M07-A10.

16. Slot DE, De Geest S, van der Weijden FA, Quirynen M. Treatment of oral malodour. Medium-term efficacy of mechanical and/or chemical agents: a systematic review. J Clin Periodontol. 2015 Apr;42(Suppl 16):S303-16. http://dx.doi.org/10.1111/jcpe.12378. PMid:25682952. 
17. Garcia-Godoy F, Klukowska MA, Zhang YH, Anastasia MK, Cheng R, Gabbard M, et al. Comparative bioavailability and antimicrobial activity of cetylpyridinium chloride mouthrinses in vitro and in vivo. Am J Dent. 2014 Aug;27(4):185-90. PMid:25831600.

18. James P, Worthington HV, Parnell C, Harding M, Lamont T, Cheung A, et al. Chlorhexidine mouthrinse as an adjunctive treatment for gingival health. Cochrane Database Syst Rev. 2017 Mar;3:CD008676. http://dx.doi.org/10.1002/14651858.CD008676.pub2. PMid:28362061.

19. Furiga A, Dols-Lafargue M, Heyraud A, Chambat G, Lonvaud-Funel A, Badet C. Effect of antiplaque compounds and mouthrinses on the activity of glucosyltransferases from Streptococcus sobrinus and insoluble glucan production. Oral Microbiol Immunol. 2008 Oct;23(5):391-400. http://dx.doi.org/10.1111/j.1399-302X.2008.00441.x. PMid:18793362.

20. Liu J, Ling JQ, Wu CD. Cetylpyridinium chloride suppresses gene expression associated with halitosis. Arch Oral Biol. 2013 Nov;58(11):1686-91. http://dx.doi.org/10.1016/j.archoralbio.2013.08.014. PMid:24112735.

21. Pan PC, Harper S, Ricci-Nittel D, Lux R, Shi W. In-vitro evidence for efficacy of antimicrobial mouthrinses. J Dent. 2010 Jun;38(Suppl 1):S16-20. http://dx.doi.org/10.1016/S0300-5712(10)700063. PMid:20621239.

22. Evans A, Leishman SJ, Walsh LJ, Seow WK. Inhibitory effects of antiseptic mouthrinses on Streptococcus mutans, Streptococcus sanguinis and Lactobacillus acidophilus. Aust Dent J. 2015 Jun;60(2):247-54. http://dx.doi.org/10.1111/adj.12312. PMid:25989101.

23. Thomas EL, Milligan TW, Joyner RE, Jefferson MM. Antibacterial activity of hydrogen peroxide and the lactoperoxidase- hydrogen peroxide-thiocyanate system against oral streptococci. Infect Immun. 1994 Feb;62(2):529-35. PMid:8300211.

24. Ten Cate JM. Contemporary perspective on the use of fluoride products in caries prevention. Br Dent J. 2013 Feb;214(4):161-7. http://dx.doi.org/10.1038/sj.bdj.2013.162. PMid:23429124.

25. Dinwiddie MT, Terry PD, Chen J. Recent evidence regarding triclosan and cancer risk. Int J Environ Res Public Health. 2014 Feb;11(2):2209-17. http://dx.doi.org/10.3390/ijerph110202209.

PMid:24566048.

\section{CONFLICTS OF INTERESTS}

The authors declare no conflicts of interest.

\section{*CORRESPONDING AUTHOR}

Rafael Nóbrega Stipp, UNICAMP - Universidade Estadual de Campinas, Faculdade de Odontologia de Piracicaba, Departmento de Diagnóstico Oral, Av. Limeira, 901, 13414-903 Piracicaba - SP, Brasil, e-mail: rafaelns@fop.unicamp.br

Received: December 3, 2018

Accepted: February 19, 2019 